AL. $2.1985 \cdot 1045$

\title{
DETERMINING REPLACEMENT VALUE OF TREES AND SHRUBS IN ALBERTA
}
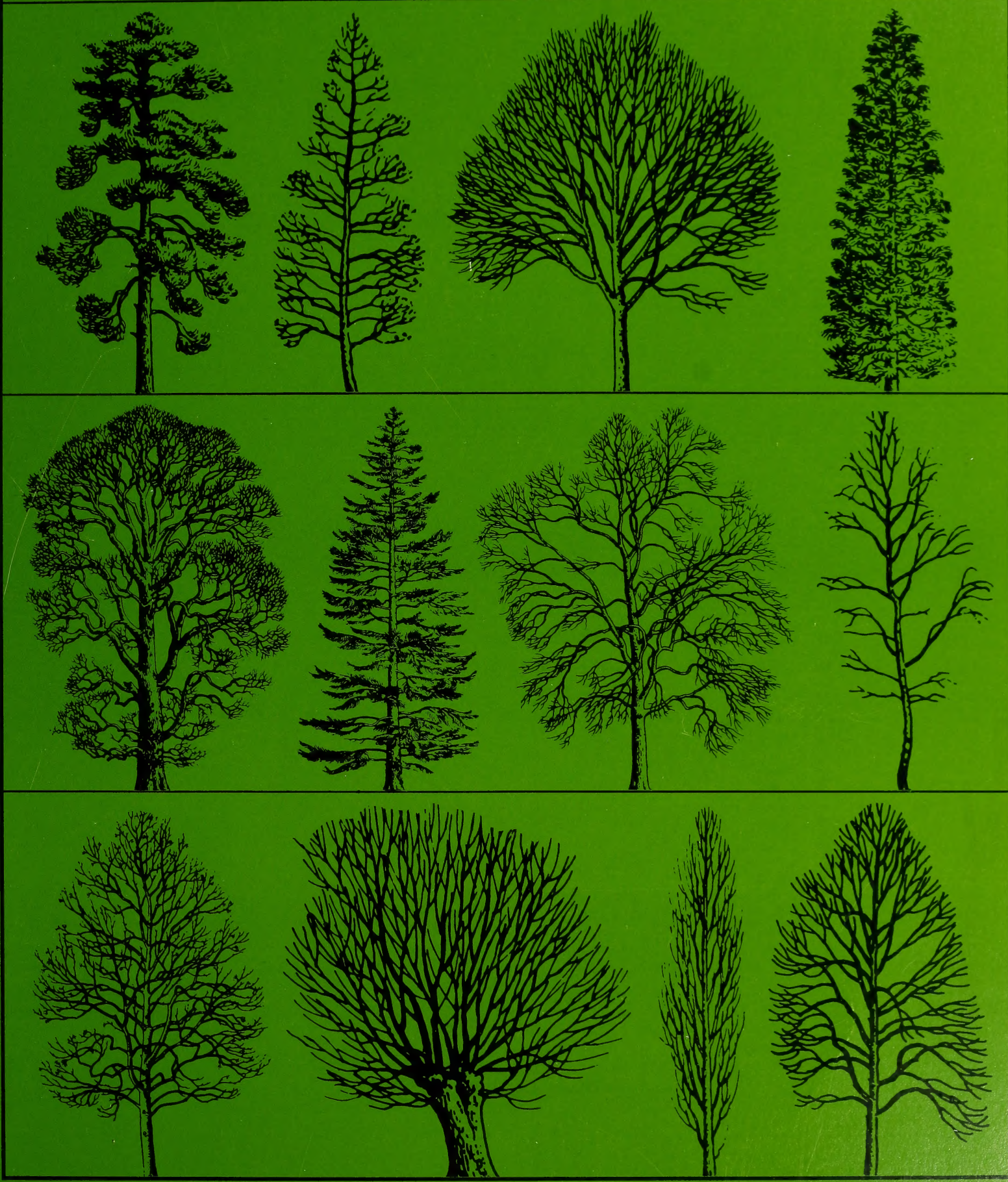

AGDEX 275/33-2 
Copies of this publication may be obtained from:

Print Media Branch

Alberta Agriculture

7000 - 113 Street

Edmonton, Alberta, T6H 5T6

OR

Alberta Agriculture's district offices 


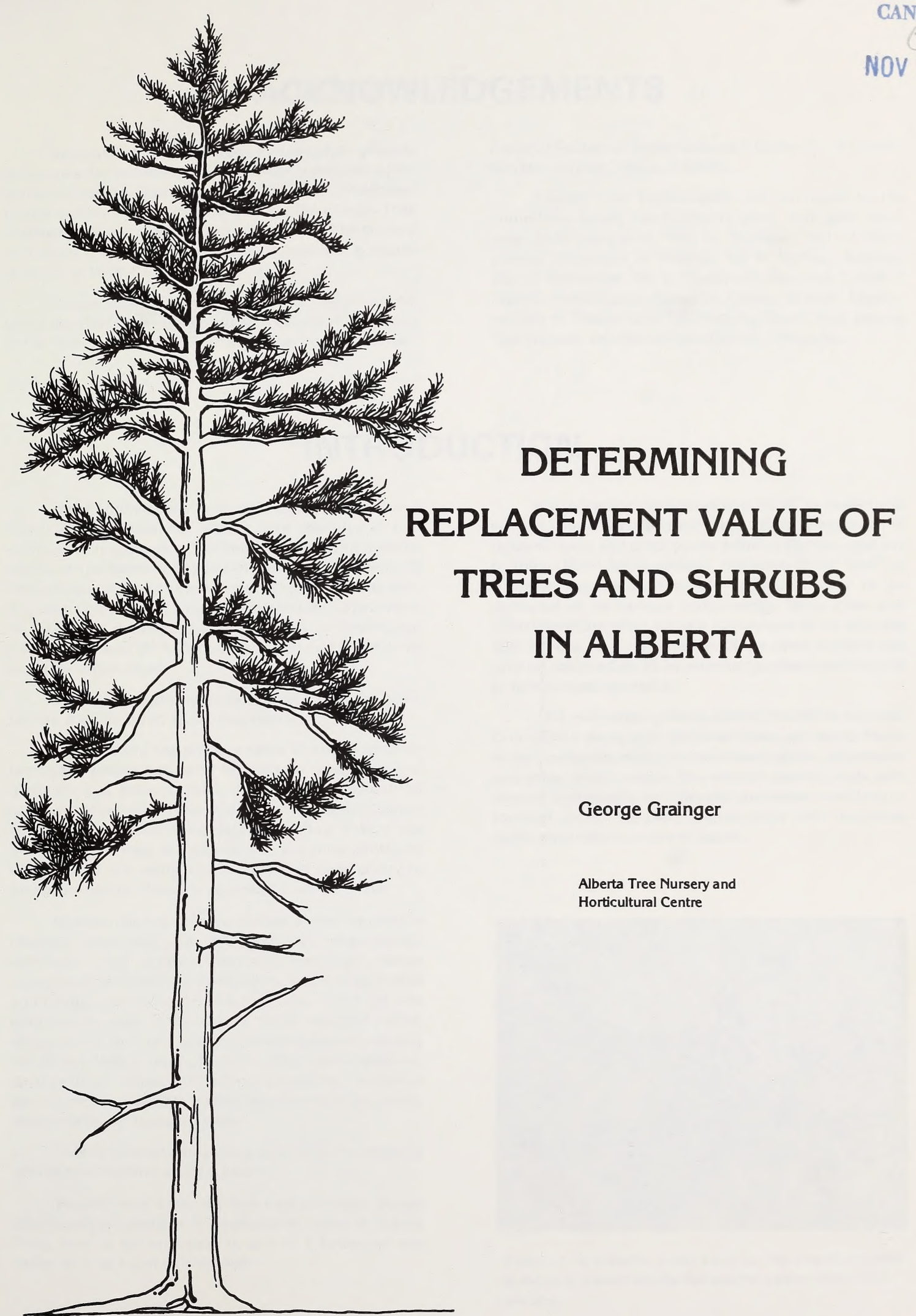


Digitized by the Internet Archive in 2015

https://archive.org/details/determiningrepla00grai 


\section{ACKNOWLEDGEMENTS}

This publication has been prepared to provide guidelines for establishing values for trees and other plants in Alberta. Many professionals have contributed to the concept of evaluating plants. The Shade Tree Evaluation Guide was first printed in 1947. The council of Tree \& Landscape Appraisers completed a fourth revision in 1979

This publication is a supplement (for use in Alberta) to the booklet Guide for Establishing Values of Trees and Other Plants. That booklet is available from ISA (Inter- national Society of Arboriculture) P. O. Box 71, 5 Lincoln Square, Urbana, Illinois 61801

Thanks and appreciation are extended to the committee which rated Alberta stock and gave other invaluable assistance. Prof. H. Knowles, Prof. of Horticulture, University of Alberta; Mr. R. Nyroos, Arborist, City of Edmonton; Mr. B. Casement, Research Scientist, Alberta Horticultural Research Center, Brooks, Alberta; and Mr. H. Oosterhuis, Tree Planting Supervisor, Alberta Tree Nursery and Horticulture Centre, Edmonton.

\section{INTRODUCTION}

Trees, individually and collectively, have many functional and aesthetic values. The objective of this publication is to provide ( 1 ) a method by which a plant or plants can be examined to determine a realistic value, (2) consulting arborists and professional horticulturists with a system for assessing natural casual losses, (3) a means of appraising damage due to accidental or intentional trespassing, and (4) information to be used by cities to evaluate urban trees.

Species, size and physical condition are the basic factors considered in appraising plants.

Traditionally, the primary value of trees and other landscape plants has been focused on their aesthetic qualities and beauty. Such qualities are difficult to quantify. However, trees and other landscape plants have assets beyond their aesthetic value. Plants are living objects; they are engaged in the most profound creativity in the world and, because of their ability to photosynthesize, they are essential to all mankind.

Shade trees and other landscape plants are used as planting elements for architectural, engineering, aesthetic, and climatic control purposes. Noise abatement, atmospheric purification, traffic control and controlling glare and reflection are some of the engineering uses of the plants. Solar radiation, wind, temperature, and precipitation modification are among the climatological uses of plants. Other considerations, such as timber value, fruit and nut production, as well as contributions to wildlife habitat and recreational activity, may be relevant in certain cases.

Trees and other landscape plants enhance property values and increase a city's assets.

Professional arborists and horticulturists should continually emphasize the functional value of plants. Trees have to be evaluated as part of a functional unit rather than as a unit on their own.
It is generally considered that "land" is made up of various components including soil, grass cover, water (if present), trees and other plants growing thereon, and any buildings that may be present. The value of the "land" as a whole can be legitimately calculated only by an appraisal of its various components. Since trees and other plants are often a major component of the land and add value to it, the evaluation of the plant material can only be achieved by an experienced professional arborist or horticultural appraiser.

This evaluation guide is divided into three sections. One section deals with specimen trees and plants found in the landscape, and includes trees in parks, arboretums and other public areas. The second section deals with trees in shelterbelts (windbreaks) and other woodland or forested areas. The third section deals with replanting native sites with a variety of plants.

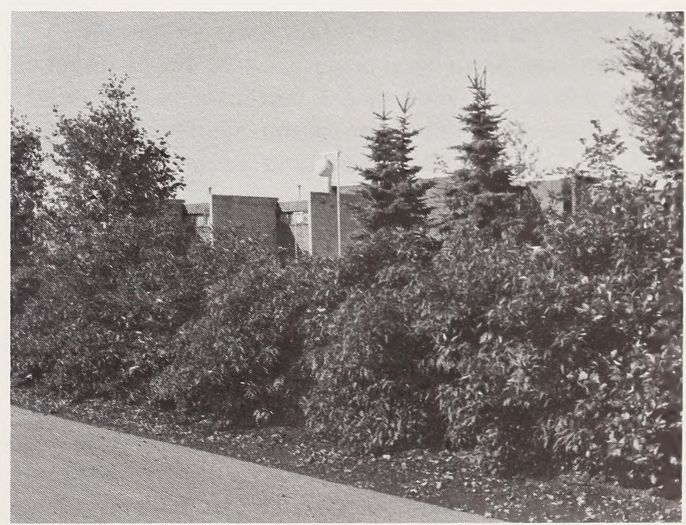

Figure 1. In a buffer zone, such as the one illustrated, a value is placed on the functional use of trees and shrubs. 


\section{GENERAL CONSIDERATIONS TO APPRAISAL}

Any means or formula for evaluating shade trees must be flexible. No hard and fast rules can be set that will hold in all cases. Instances undoubtedly will be encountered of such remarkable specimens that the basic value might be higher than usual. This is a matter for the appraiser's judgment as is the condition class for any tree.

The appraiser must decide whether it is desirable to consider matters not included in the formula, such as the effect of land value or any other factor believed to influence the value of the particular tree. The judgment and opinion of the appraiser will always be important in determining the value. An arborist or horticulturist familiar with the characteristics of the trees being appraised, through experience with trees in landscape plantings, and who is capable of placing individual specimens in their proper classification and condition classes, must make the appraisal.

The lists of Trees of Alberta (Appendix I) prepared by the authors are not "all inclusive" nor are they the final word. Changes and upgrading will be necessary in order to keep abreast of the many cultivars and new plant introductions. There are many cultivars and even some species that have not been included because of the lack of sufficient data for proper classification. In most cases cultivars of species were not classified. Consequently, the proper classification of the cultivars of several genera, such as Populus and Salix, is left to the judgment of the qualified arborist or horticulturist confronted with the appraisal.

This evaluation guide makes use of two methods to enable the professional arborist to establish a monetary value for a tree: (1) replacement and (2) a basic formula geared to a monetary value per sectional square centimetre of trunk diameter. The replacement and basic formula values are subjected to various percentage evaluations for species, condition, and location. The monetary unit established must be flexible to allow for changes in the value of the dollar and known costs of conducting horticultural practices. 


\section{SECTION ONE SPECIMEN TREES AND SHRUBS REPLACEMENT VALUE}

Most small trees have a replacement value. It is suggested that when a definite replacement value can be established for a particular tree that this be used. For medium and large shade trees where a replacement value is impractical, the basic formula method, which will be described, is more practical.

It should be understood that this method for evaluating shade and ornamental trees is intended for use with specimen trees in landscape designs or street plantings rather than for park and forested areas. Unrealistic values may be obtained by applying it to trees in group plantings. For example, a group of three trees growing close together might be of no more value to the landscape than one single specimen tree. When used on trees growing in groups, the appraiser will need to introduce a percentage factor, based on his judgment, by which the values of the individual trees of the group should be reduced. The same procedure may be necessary in dealing with trees having multiple trunks, although in a particular landscape design a multiplestemmed tree may be especially desirable and have full or extra value.

For trees in parks reasonable values can be established by the basic formula method. The formula can be found in the booklet available from the International

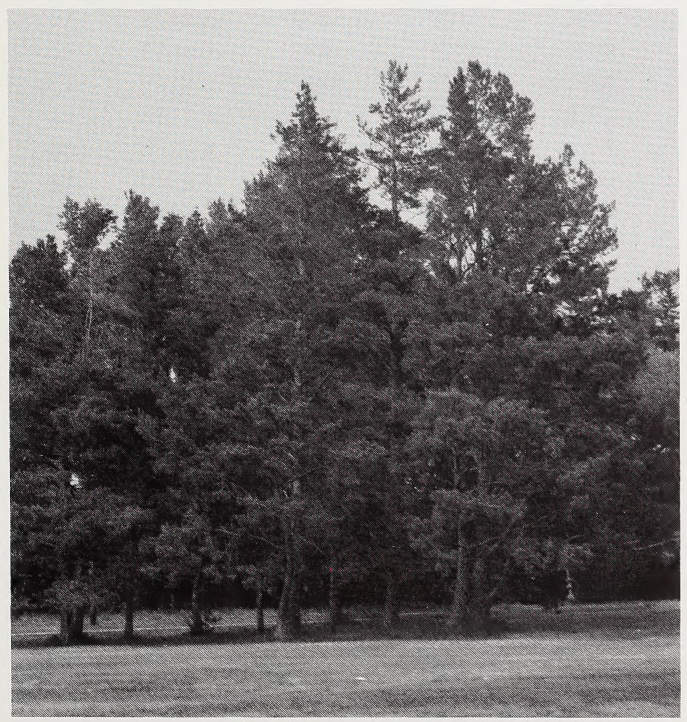

Figure 2. In a park setting the value of an individual tree growing in a group may be less than that of a single tree by itself.
Society for Arboriculture. (See acknowledgements) Because the area is a park, trees are definitely worth more than their timber value. In this instance, experienced people must select a percentage factor that in their opinion represents the difference in value of the particular park trees and that specified by the use of the formula. It is quite possible that a lawn specimen tree may have a different value from a street tree because of its low branching habit, or it may have had better maintenance producing a better structure or a healthier plant

Usually the appraiser can establish replacement values through actual quotations from local nurserymen, landscape contractors, or by reference to nursery catalogues. Where no values for specific species or cultivars can be established, the appraiser may be forced to use prices listed for plants of similar kind and size

If replacement costs must be computed, such factors as tree or plant cost, availability, labor costs, special area problems, the cost of removing the casualty trees or plants, restoration of the casualty area, guarantees, maintenance and other unusual conditions or problems, as well as profit, must be considered. Transportation distances may make replacement costs excessive.

Table 1 has been prepared to aid the appraiser in establishing values for transplanting-size trees in areas where difficulty is experienced in obtaining cost estimates. Replacement cost estimates were based on the following specifications: "cost to include cost of the plant, properly sized, guaranteed for one year, guyed, wrapped and otherwise treated according to standard arboricultural practices.

Standards state that the caliper of the trunk shall be taken $15 \mathrm{~cm}$ above ground level up to and including $10 \mathrm{~cm}$ caliper size, and $1.5 \mathrm{~m}$ above ground level for larger sizes. These positions of caliper measurement conform to the usual bidding specifications for purchase contracts and planting cost calculations by landscape architects, landscape contractors, and arborists.

Replacement costs of trees are subject to many variables, including labor costs, availability of planting stock and site variations, and factors prevailing in different parts of the country. These variables necessitate a spread in the estimated replacement costs. Currently, most estimates will fall within the range or within 10 to 15 percent of the range indicated in Table 1. However, local replacement costs should prevail. The figures in Table 1 may apply to both deciduous and evergreen trees, especially in the larger sizes. Costs of evergreen trees of the smaller caliper sizes are usually calculated on a height basis. 
TABLE 1

AVERAGE REPLACEMENT COST OF TREES

\begin{tabular}{cc}
\hline $\begin{array}{c}\text { *Trunk Caliper } \\
\text { in Centimetres (inches) }\end{array}$ & $\begin{array}{c}\text { Basic Replacement } \\
\text { Cost (1985\$) }\end{array}$ \\
\hline $5.0(2)$ & $180-200$ \\
$7.5(3)$ & $240-320$ \\
$10.0(4)$ & $340-480$ \\
$12.0(5)$ & $540-710$ \\
$15.0(6)$ & $730-840$ \\
$17.5(7)$ & $900-1050$ \\
\hline
\end{tabular}

* Measurements: To $10 \mathrm{~cm}$ caliper, taken $15 \mathrm{~cm}$ above ground level; $11 \mathrm{~cm}$ and more in caliper, taken $1.5 \mathrm{~m}$ above ground level.

Replacing a tree beyond this size would be by mechanical means and involves such high moving costs that they have been deleted from this list. The moving costs may exceed the value of a tree and make the dollar cost unrealistic. Therefore, replacement should be used only for trees of $5-17.5 \mathrm{~cm}$.

One may be entitled to full remuneration of replacement cost for a casualty. Allowances should be subject to species, condition, and location factors. For example, if a low rating tree species in poor physical condition becomes a casualty during a storm, one should not expect full remuneration or replacement. A qualified professional horticulturist will be capable of making the proper adjustment.

The use of the basic formula method in tree appraisal depends upon field inspection and complete diagnosis of the tree or trees involved. Field records and photographs are important. Leave no details to memory. The Council of Tree and Landscape Appraisers has prepared an illustrated field report folder for recording field data as a model. 
TABLE 2

BASIC EVALUATION OF TREES CALCULATED ON CROSS-SECTION AREA OF TRUNK

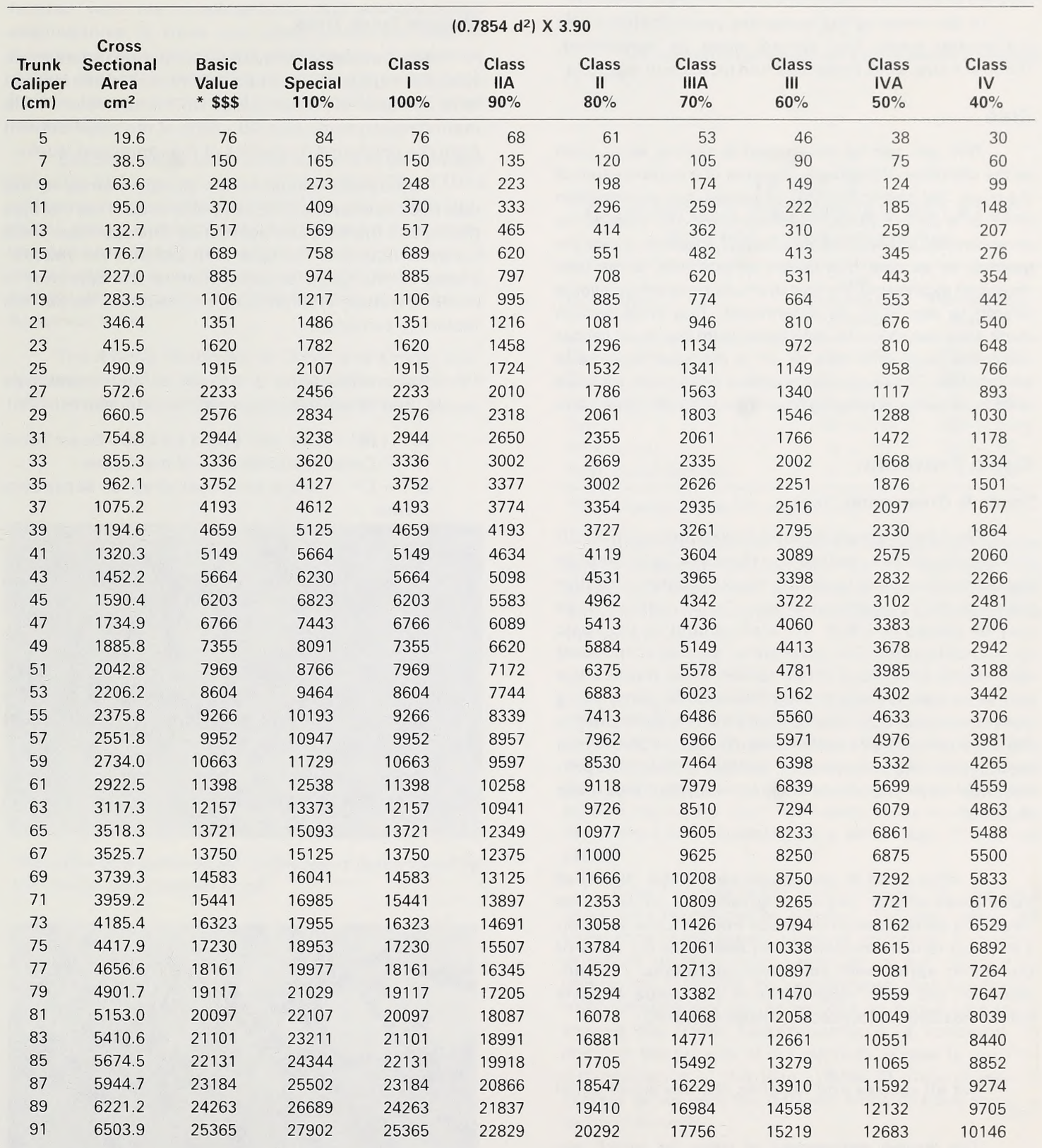

${ }^{*}$ Calculated on $\$ 3.90$ per square centimetre of cross-section trunk area at: $15 \mathrm{~cm}$ height up to $10 \mathrm{~cm}$ diameter and $1.5 \mathrm{~m}$ above the ground or as near as possible to that height for larger sizes. All dollar values are rounded to the next full dollar. 


\section{PLANT EVALUATION}

\section{TREES}

In determining the monetary value of shade and ornamental trees, four factors must be considered. These are size, kind, condition, and location of the trees.

\section{Size}

Tree size can be designated in several ways, such as the diameter of the trunk, the area of a cross-section of the trunk, the height, the branch spread, or a combination of all or a part of these measurements. The area of the cross-section of the trunk at a point 1.5 metres above the ground, or as near this height as possible, is the best means of expressing the size of shade trees when a value related to size is to be determined. This cross-section trunk area can easily be calculated from the trunk caliper using the formula $0.7854 \mathrm{~d}^{2}, \mathrm{~d}^{2}$ is diameter squared in centimetres. These calculations have been made for trees with trunk calipers ranging from $5 \mathrm{~cm}$ to $91 \mathrm{~cm}$. (See Table 2).

\section{Basic Formula:}

\section{Shade \& Ornamental Trees}

The basic formula method is used for trees over 30 $\mathrm{cm}$ in diameter. It is realized that there is a "gray area" in the differentiation of trees into sizes indicating whether they can be transplanted or not. Certain caliper trees may be placed in either the replacement or the basic formula categories. The use of either method of appraisal may reflect either high or low values. In such cases, the appraiser may average out the values obtained by using both methods of appraisal or select the one he decides is the most fair and reasonable based on sound procedural techniques. The replacement method should take precedence over the basic formula method wherever possible.

A value of $\$ 3.90$ per square centimetre (1985\$) of trunk cross-section has been given as a conservative value of a perfect specimen shade tree. No price set upon a tree will remain constant for all time since the value of our dollar varies with economic conditions. For convenience, the basic value for each centimetre of trunk caliper has been calculated and listed in Table 2 .

Not all species and varieties of trees are of equal value.

The largest percentage of trees for which ap praisals will be required in Alberta will be below $60 \mathrm{~cm}$.

Classification calculations are listed at $10 \%$ intervals. The user should understand that any interval can be used. The authors used this broad range to group a large number of species.

\section{Multiple Trunk Trees}

Several methods have been employed to determine values of multiple trunk trees. The most common method is to compute the value based on the diameter of the main (largest) trunk plus $40-60 \%$ of the value derived from the combined diameters of the remaining trunks

Values determined by the canopy method do not take into consideration the aesthetic value of the multiple trunks and the bark characteristics. The appraiser must consider how well the specimen satisfies the requirements of the given situation before the appraisal is made. Location, environment and aesthetic values are factors to consider.

Basic formula for a 3 stem multiple trunk tree would then be (all measurements in centimetres)

$$
\begin{aligned}
& A^{2}+\left(\left(B^{2}+C^{2}\right) \times 40-60 \%\right) \times \$ 3.40=\text { Basic Value } \\
& A^{2}=\text { Cross-sectional area of main stem } \\
& B^{2}+C^{2}=\text { Cross-sectional area of secondary } \\
& \text { stems }
\end{aligned}
$$

\section{Species}

There will be disagreement as to the rating given any species or cultivar. These differences may include such factors as relative hardiness, structural strength, durability and life expectancy, cleanliness, resistance to insects and diseases, and environmental and aesthetic value. Hardiness is considered a most important point in species rating, but usually in appraisal work the plant will not be present unless it is hardy.

Site adaptability is an important factor in species rating. For example, Tilia cordata, Little Leaf Linden, is

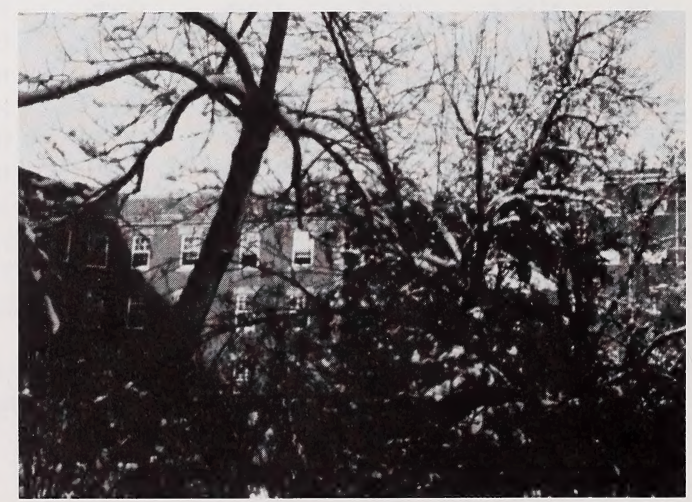

Damage to individual trees from construction should be compensated for 
an excellent lawn tree for most residential areas but it is not well adapted to industrial areas and thus would have a different species rating in the two sites

Qualified professional arborists and horticulturists, familiar with the characteristics and environmental adaptabilities of trees and other plants are able to determine the correct species classification. Percentage ratings depend on many factors, some extremely local. Ratings based on zone cold-hardiness alone are often misleading

Species and cultivar rating can be any percentage from 1 to 110 percent. A tree of high value (80-110\%) will possess the qualities of hardiness, reasonable durability, and wide adaptability. It will require little maintenance and is free from undesirable characteristics. It should possess a sturdy branching habit and pleasing foliage, and may have the added features of interesting flowers or fruits.

The Alberta Horticultural Guide and similar publications will aid in the determination of recommended trees, shrubs and evergreens for use in Alberta.

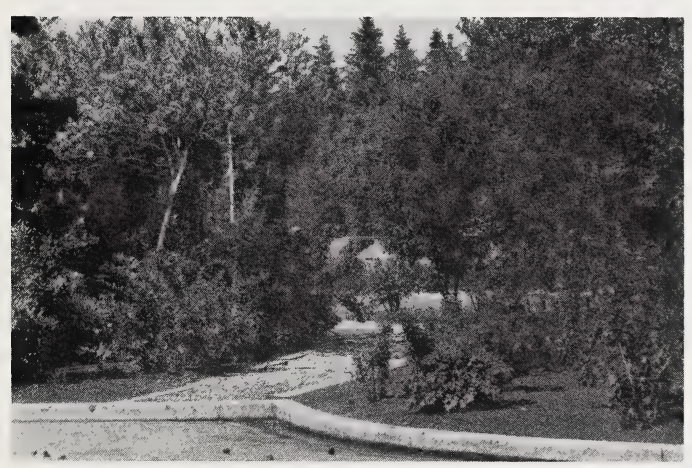

The value of a commercial landscape is determined by the design and material used.

\section{Condition}

Very few trees or shrubs are perfect specimens. A qualified professional plant person able to recognize and quantify the tree or plant condition and relate it to a perfect specimen is required.

As trees reach maturity they often develop structural weaknesses or other physical defects. Crowded, overgrown plants may fail to satisfy the requirements of a given landscape situation. Such specimens may even have a negative value and would improve aesthetic and functional values if removed
Annual growth rate, extent of decay, structural weakness, freedom from insects and disease, ability to survive, and life expectancy of the plant or plants are factors to consider in determining the condition rating. Complete diagnosis of the physical condition of the plant is important.

The condition rating can be expressed as a percent (1 - 100).

TABLE 3

\section{CONDITION RATING AS RELATED TO LIFE EXPECTANCY}

\begin{tabular}{lcc}
\hline Condition & $\begin{array}{c}\text { Life } \\
\text { Expectancy } \\
\text { *Years) }^{\text {(Year }}\end{array}$ & $\begin{array}{c}\text { Percentage } \\
\text { Rating }\end{array}$ \\
\hline Excellent & Over 30 & $90-100$ \\
Good & $20-30$ & $80-90$ \\
Fair to good & $15-20$ & $60-80$ \\
Fair & $10-15$ & $40-60$ \\
Poor to fair & $5-10$ & $20-40$ \\
Poor, rapid decline & $0-5$ & $0-20$ \\
\hline
\end{tabular}

* Years beyond year of inspection.

The determination of the life expectancy is flexible and is based on the judgment of the appraiser. The severity of the defect, the type of fault and the consequences of the problem continuing are fundamental to the determination.

Injury can occur to the roots, trunk or crown of the tree. Earth fills, trenching, even toxic gases can injure roots; people and cars are some of the causes of trunk injury, and storms may result in broken branches reducing crown extent and condition. Where injury occurs, the appraiser will first evaluate the tree as it was prior to the injury. Then the extent of the injury will be established and expressed as a percentage of the total value.

Extent of root injury from cuts and fills and toxic gases may be difficult to establish, but here again, the knowledge of the expert becomes important. The extent of injury to trunk and cambium is not difficult to determine. It should be remembered that lengthwise trunk injuries are not as serious as those extending around the trunk. Consequently, it is necessary to consider the breadth of the injury in relation to the total circumference of the trunk (Table 4). Rate of wound healing varies with the different kinds of trees and is a factor to consider.

Extent of crown injury by missing, broken, or otherwise injured branches can be fairly accurately estimated. Several points need to be considered. First, the ability of the plant to develop a new crown or replace a portion of its crown. Second, the effect of age on the rate of crown redevelopment. A third point to consider is the cost and extent of corrective pruning necessary to improve and extend the life expectancy of the tree and its aesthetic and functional values. 
TABLE 4

DIMINUTION IN VALUE AS RELATED TO PARTIAL INJURY*

\begin{tabular}{|c|c|}
\hline $\begin{array}{c}\text { Bark and cambium injury } \\
\% \text { of total trunk } \\
\text { circumference }\end{array}$ & $\begin{array}{l}\text { Reducing value } \\
\text { by percent }\end{array}$ \\
\hline Up to 20 & At least 20 \\
\hline 25 & 25 \\
\hline 30 & 35 \\
\hline 40 & 70 \\
\hline 45 & 90 \\
\hline 50 & 100 \\
\hline
\end{tabular}

${ }^{*}$ Percentages taken from Table 7, page 322, Tree Ecology and Preservation by A. Bernatzky. 1978.

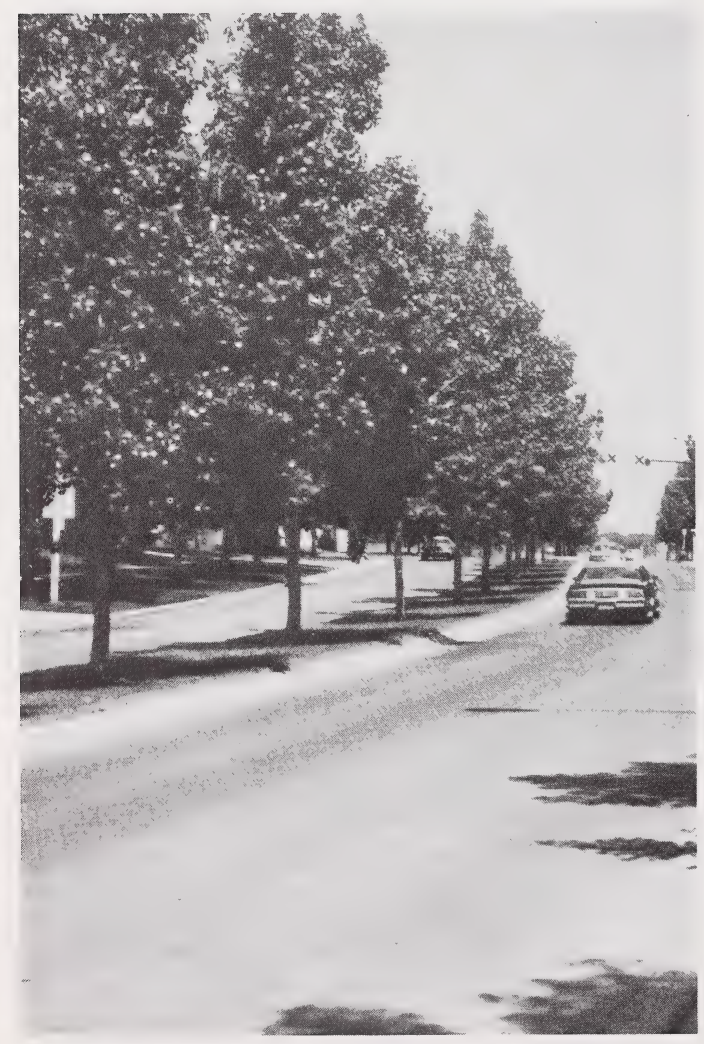

Trees of the same type grown as boulevard trees, as shown, will probably have a lower value than if grown alone in a park.
TABLE 5

\section{GUIDE FOR JUDGING THE CONDITION OF A SHADE TREE}

\begin{tabular}{|c|c|c|}
\hline Factor & Condition ${ }^{1}$ & $\begin{array}{l}\text { Points } \\
\text { Awarded }\end{array}$ \\
\hline $\begin{array}{l}\text { Trunk } \\
\text { condition }\end{array}$ & $\begin{array}{l}\text { Sound and solid (5) } \\
\text { Sections of bark missing ( } 3 \text { ) } \\
\text { Extensive decay (1) }\end{array}$ & \\
\hline Growth rate & $\begin{array}{l}\text { More than } 15 \mathrm{~cm} \text { twig } \\
\text { elongation ( } 3 \text { ) } \\
5-15 \mathrm{~cm} \text { twig elongation (2) } \\
\text { Less than } 5 \mathrm{~cm} \text { twig } \\
\text { elongation (1) }\end{array}$ & \\
\hline Structure & $\begin{array}{l}\text { Sound (5) } \\
\text { One major or several minor } \\
\text { limbs dead (3) } \\
\text { Two or more major limbs } \\
\text { dead (1) }\end{array}$ & \\
\hline $\begin{array}{l}\text { Insects and } \\
\text { diseases }\end{array}$ & $\begin{array}{l}\text { No pests present (3) } \\
\text { One pest present (2) } \\
\text { Two or more pests present } \\
\text { (1) }\end{array}$ & \\
\hline $\begin{array}{l}\text { Crown } \\
\text { development }\end{array}$ & $\begin{array}{l}\text { Full and balanced ( } 5 \text { ) } \\
\text { Full but unbalanced ( } 3 \text { ) } \\
\text { Unbalanced and lacking a } \\
\text { full crown (1) }\end{array}$ & \\
\hline $\begin{array}{l}\text { Life } \\
\text { expectancy }\end{array}$ & $\begin{array}{l}\text { Over } 30 \text { years }(5) \\
15-20 \text { years }(3) \\
\text { Less than } 5 \text { years }(1)\end{array}$ & \\
\hline . & TOTAL POINTS & 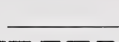 \\
\hline
\end{tabular}

\begin{tabular}{ccc}
\hline Total Points & Condition Class & $\begin{array}{c}\text { Formula Percentage } \\
\text { for } \\
\text { Condition }\end{array}$ \\
\hline $26-23$ & Excellent & $80-100$ \\
$22-19$ & Good & $60-80$ \\
$18-14$ & Fair & $40-60$ \\
$13-10$ & Poor & $20-40$ \\
$9-6$ & Very Poor & $0-20$ \\
\hline
\end{tabular}

\section{Location}

Location is the factor that takes into account site, function, position, and aesthetic value.

(1) Site: the relationship of the tree to its surroundings.

(2) Function: benefits the plant provides such as wind, noise, and temperature control

(3) Position: where situated, boulevard, front lawn, shelterbelt, etc

(4) Aesthetic value: the value of the plants' characteristics, such as flowers, foliage color or type, fruit and bark characteristics. 
There will be overlap between species and location. Flowers may be a characteristic of the species but because of its location flowers may add or detract from the value of the specimen.

The location factor will allow the qualified professional horticulturist to consider the importance of the tree or trees from an architectural, engineering, climatic, and aesthetic viewpoint. Architecturally, trees may function to articulate space, soften architectural structure, provide privacy and screen unsightly views or objects, or emphasize off-site views. Air filtration through absorption of dirt and dust, purification of the atmosphere by emission of oxygen, noise abatement, lightning protection, preventing glare and reflection, prevention of soil erosion by wind and water, traffic direction, screening ski slopes to prevent snow melting, and use in preventing snow drifting may be classified as engineering functions of trees and other plants.

The appraiser should not overlook the aesthetic aspects and other quality values which, traditionally, have been considered of major importance. Branching habit, bark characteristics, foliage effects, flower and fruit characteristics may all add to the aesthetic value of trees. Trees may also furnish food and fibre for man and wildlife, and decrease mental stress. Thus, the location factor measures the "benefits" derived from the plants. The functional purposes served by plants in controlling environmental quality may be measured and, in fact, have been measured by scientists over the years.

The functional capabilities of trees become allimportant in appraisals. The location of any tree or group of trees is a determining factor in evaluation. Trees growing in unimproved or natural wooded areas have a different value from trees on improved property. Street trees, park trees, and trees in recreational areas have a completely different set of values from those growing on improved residential property. A single tree on a residential property has greater value than an individual tree in a group.

Balance and concept of the landscape design should be considered in assessing tree values. The loss of a single tree in a formal design may destroy the effectiveness of the whole design

The growth potential should be considered in thie evaluation process. Will the size of the tree in a few years interfere with overhead or underground utility facilities?

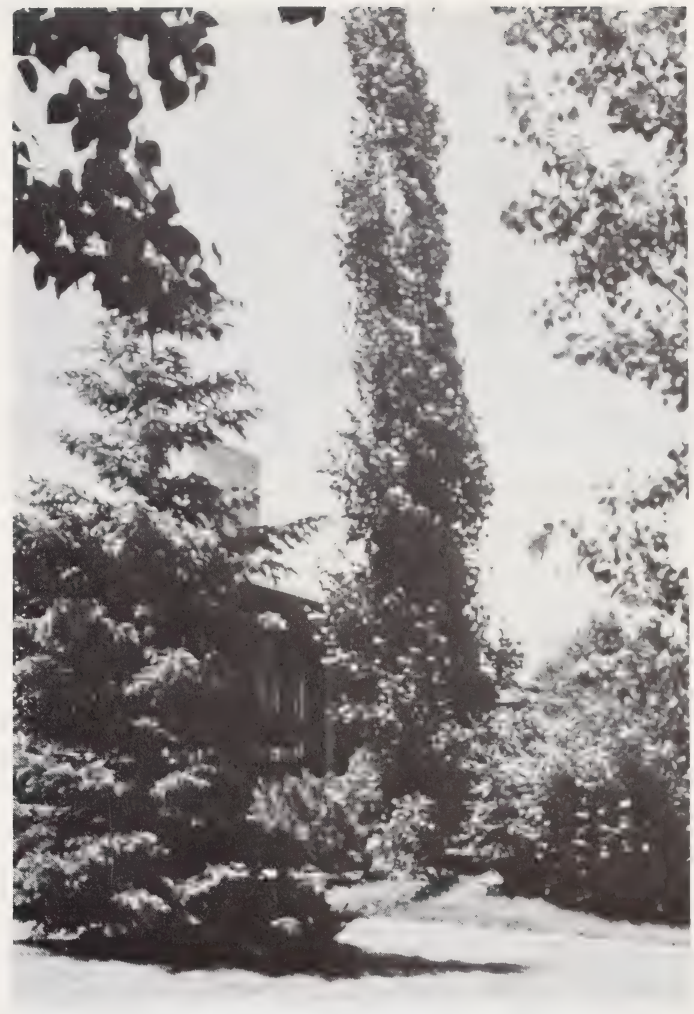

Two high value lawn specimen trees.

TABLE 6 EVALUATION OF TREE LOCATION

\begin{tabular}{lc}
\hline Location & $\begin{array}{c}\text { Percentage } \\
\text { Rating }\end{array}$ \\
\hline Feature or historical trees (Arboretum) & $90-100$ \\
Average residential, landscape trees & $80-90$ \\
Malls & $75-85$ \\
Public and commercial area trees & $70-80$ \\
Park trees & $60-80$ \\
Golf course trees, strategically located & $60-80$ \\
City streets and boulevards & $60-80$ \\
Screen and windbreak trees** & $60-70$ \\
Recreational and picnic area trees & $60-70$ \\
Industrial area trees & $50-70$ \\
Out of city highway trees & $40-60$ \\
Native, open woods trees & \\
Dense forest trees* & $30-40$ \\
\hline
\end{tabular}

* Does not include areas under forest management

** Screen and shelterbelt trees are considered in more detail in a following section. 


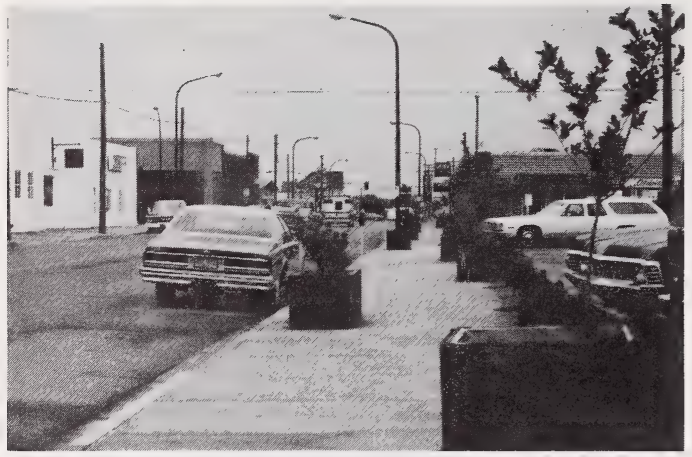

Small evergreens in such locations have a high value.

\section{SHRUBS \& SMALL EVERGREENS}

The evaluation of shrubs and small evergreens is somewhat different from that for trees. Consideration must be given to the overall landscape design of the property and the functional value of the plants in respect to such factors as traffic articulation, privacy screening, noise abatement, and climate control. Also the aesthetic values of such plants should not be ignored.

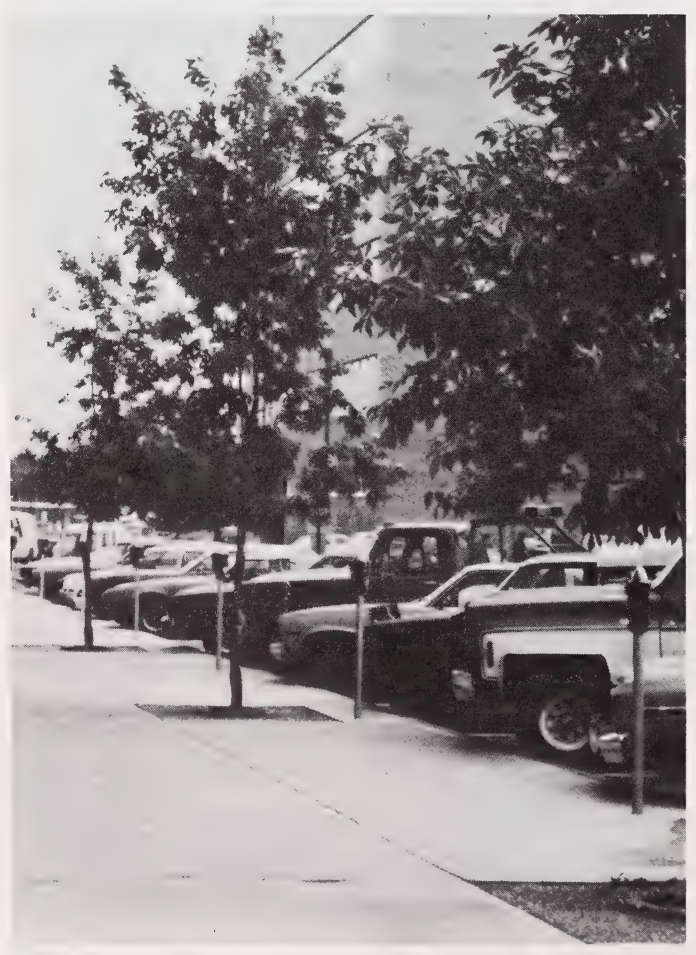

Street trees such as these should be given a high value because of function performed.
The following steps are basic in this evaluation process. The factor selected in each case is a percentage of the wholesale value of nursery or garden centre stock available. Particular species or cultivars must be used.

Wholesale prices for deciduous shrubs and small evergreens are so variable that it is impossible to establish average prices that will give realistic replacement costs. With many deciduous shrubs it is possible to rejuvenate damaged plants by the total removal of all top growth.

\section{Location}

Table 7 may be considered as a guideline for evaluating site and functional values of specimen shrubs and small evergreens in various locations.

\section{TABLE 7}

GUIDELINES FOR EVALUATING SITE AND LOCATION FOR SPECIMEN SHRUBS AND SMALL EVERGREENS

Site - Location

Percent of

Basic Value

Foundation Plantings

$90-100$

Specimen plants properly located in a

functional landscape design

$80-100$

Plants for screen or windbreak purposes

$60-80$

Plants overgrown or with little functional or aesthetic value

$20-60$

Age

Using Table 8 attach a maturity factor to the assembly of values.

TABLE 8

\begin{tabular}{lc}
\hline Stage of Maturity & Age $\%$ \\
\hline Mature size & 100 \\
To $3 / 4$ mature size & 70 \\
To $1 / 2$ mature size & 40 \\
To $1 / 4$ mature size & 15 \\
\hline
\end{tabular}




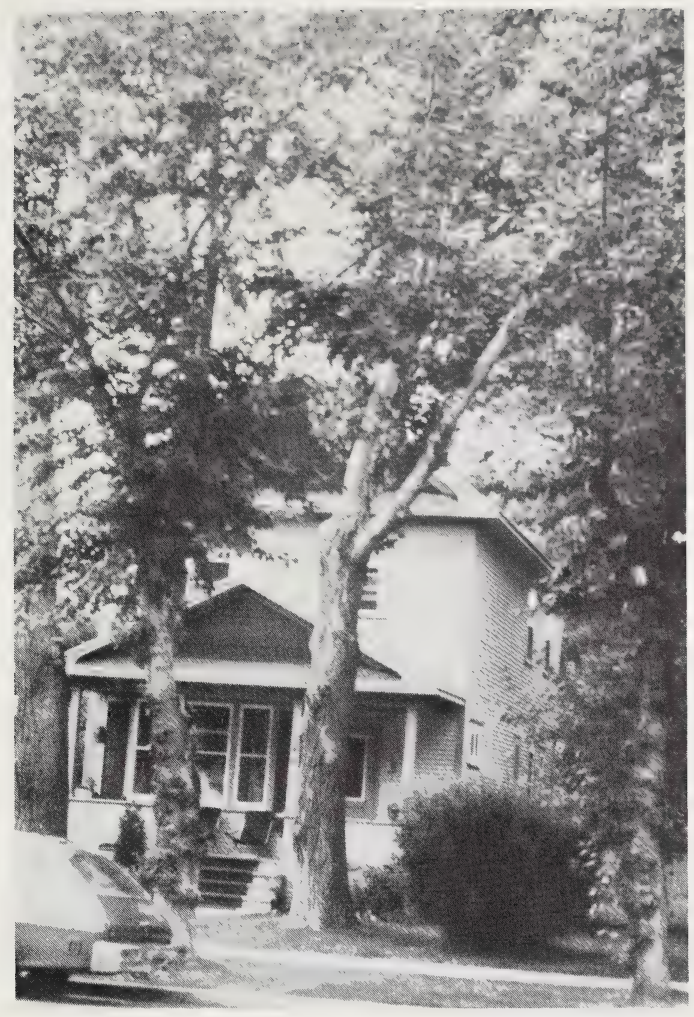

Determining the anticipated life of trees may influence the final value. The trees shown are not long-lived and are past their peak of maturity.

\section{Condition}

TABLE 9

\begin{tabular}{lc}
\hline Condition of the plant & Condition \% \\
\hline Perfect Specimen & 100 \\
Good & 90 \\
Fair to Good & 80 \\
Fair & 60 \\
Poor to Fair & 40 \\
Poor & 20 \\
\hline
\end{tabular}

\section{Planting Cost}

\section{Basic Evaluation}

The planting cost is the estimation of planting time given by competent people under existing horticulture practices.

The evaluation is then:

Wholesale Cost $X$ Species \% X Location \% $X$ Age $\%$ X Condition $\%=$ Value + Planting Cost $=$ Appraised Value \$.
Typical Example: A Cornus sericea judged to be mature.

1. Current wholesale value

(45 cm branches)

$\$ 8.50$

2. $X$ Species value \%

$\times \quad 50 \%$

3. $\times$ Location $\%$

$\$ 4.25$

4. $\times$ Age $\%$

$100 \%$

$\$ 4.25$

5. $\times$ Condition $\%$

$\$ 2.55$

5. $\times$ Condition $\%$

$100 \%$

$\$ 2.55$

6. $\quad+$ Realistic planting cost in $\$$

$\$ 20.00$

APPRAISED VALUE

$\$ 22.55$

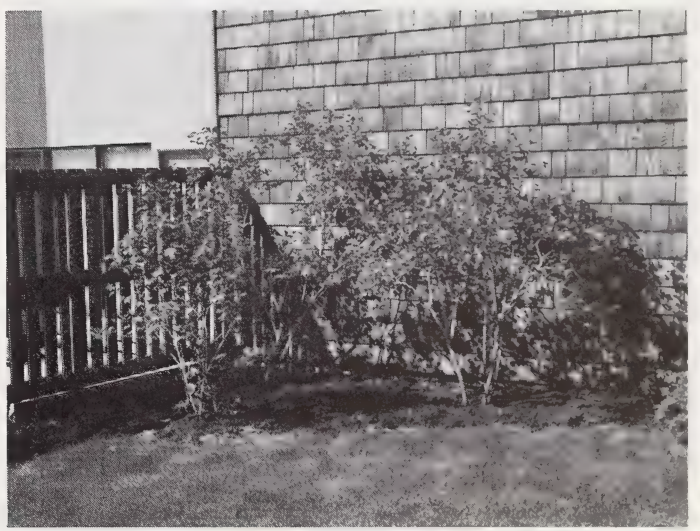

Foundation plantings are frequently given a very high value.

2. Value Deducted Evaluation (An Alternative Method)

Use Table 10 to arrive at a figure for the value of a fully mature perfect specimen. Maximum value (100\%) is given to Pinus mugo "dwarf" and Picea pungens "dwarf". This value is then used as the wholesale cost.

The percentages are taken of that value. The value then is higher but perhaps more useful especially when the replacement seriously reduces the property value.

The evaluation is then:

Basic Value $X$ Species Value \% $X$ Age $\% \quad X$ Condition \% $X$ Location \% + Realistic Planting Cost. 
1. Basic value

2. X Species value $\%$

3. $\times$ Location $\%$

4. $\times$ Age $\%$

5. $\times$ Condition \%

6. + Realistic planting cost in $\$$

APPRAISED VALUE

\begin{tabular}{|c|c|}
\hline \multirow{3}{*}{$x$} & $\$ 50.00$ \\
\hline & $50 \%$ \\
\hline & $\$ 25.00$ \\
\hline \multirow[t]{2}{*}{$x$} & $100 \%$ \\
\hline & $\$ 25.00$ \\
\hline \multirow[t]{2}{*}{$x$} & $100 \%$ \\
\hline & $\$ 25.00$ \\
\hline \multirow[t]{2}{*}{$x$} & $60 \%$ \\
\hline & $\$ 15.00$ \\
\hline+ & $\$ 35.00$ \\
\hline
\end{tabular}

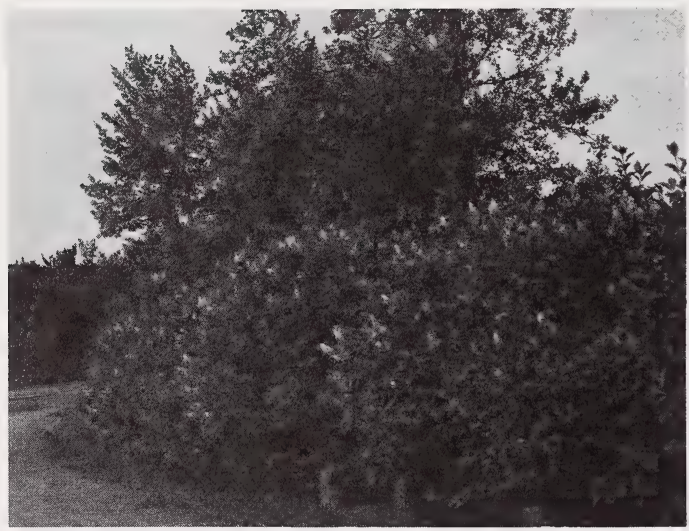

A screen planting must be assessed for the functional value as well as the aesthetic.

\section{TABLE 10}

\section{SPECIES EVALUATION}

\section{Evaluation Comparison}

\section{A. EVERGREEN SHRUBS}

RATING \%

\section{Class 1}

Picea pungens "dwarf"

Pinus mugo "dwarf"

Thuja orientalis pyramidalis

Class II

Abies pungens "dwarf"

Juniperus horizontalis

Juniperus chinensis pfitzeriana aurea

Juniperus scopulorum "Blue Heaven"

Picea abies "dwarf"

Thuja orientalis globosa

\section{Class III}

Juniperus pfitzeriana $\quad 60$

Juniperus sabina $\quad 60$

Pinus mugo $\quad 60$

\section{B. DECIDUOUS SHRUBS RATING \%}

\section{Class II}

Acer ginnala $\quad 70$

Caragana arborescens "Lorbergii" 75

Caragana arborescens pendula $\quad 80$

Caragana pygmaea $\quad 70$

Cornus alba cultivars $\quad 75$

Euonymus nana $\quad 70$

Hippophae rhamnoides (female) 75

$\begin{array}{ll}\text { Hydrangea } & 70\end{array}$

Lonicera coerulea edulis $\quad 70$

Lonicera xylosteum (dwarf) 70

Lonicera korolkowii "Zabeli" 75

Philadelphus microphyllus $\quad 75$

Potentilla fruticosa cultivars $\quad 70$

Prunus t. multiplex $\quad 85$

Prunus $X$ cistena $\quad 70$

Rose hybrids $\quad 75$

Sambucus canadensis glauca $\quad 70$

Sambucus racemosa aurea 70

Spiraea bumalda "Goldflame" 75

Syringa hybrids $\quad 85$

Syringa josiflexa $\quad 70$

$\begin{array}{ll}\text { Syringa prestoniae } & 70\end{array}$

Class III

Amelanchier alnifolia $\quad 60$

Caragana frutex globosa $\quad 65$

Cornus alternifolia $\quad 60$

Euonymus alata $\quad 60$

Lonicera tatarica cultivars $\quad 60$

Physocarpus opulifolius $\quad 60$

Physocarpus o. luteus 68

Physocarpus o. nanus 63

Prunus fruticosa $\quad 55$

Prunus japonica $\quad 65$

Prunus tenella 63

Prunus tomentosa $\quad 67$

Ribes aureum $\quad 65$

Sambucus canadensis $\quad 60$

Sambucus racemosa $\quad 62$

Sambucus racemosa cultivars $\quad 67$

Spiraea media 60

Spiraea trichocarpa $\quad 60$

Spiraea triloba $\quad 55$

Spiraea bumalda froebelii $\quad 65$

Syringa vulgaris $\quad 60$

Viburnum lantana $\quad 70$

Viburnum lentago $\quad 75$

Viburnum opulus $\quad 70$

Viburnum opulus cultivars $\quad 70$

Viburnum trilobum $\quad 60$

Viburnum trilobum cultivars $\quad 70$ 
TABLE 10 (continued) DECIDUOUS SHRUBS

RATING \%

Class IV

Caragana arborescens 40

Cornus sericea 50

Hippophae rhamnoides (male) 50

Lonicera tatarica 50

Potentilla fruticosa 50

Prunus besseyi 50

Ribes alpinum $\quad 50$

Ribes missouriensis $\quad 40$

Rosa acicularis $\quad 30$

Rosa rubrifolia $\quad 50$

Shepherdia argentea $\quad 40$

Syringa villosa $\quad 50$ 


\section{SECTION TWO WINDBREAK, SHELTERBELT EVALUATION FOR ALBERTA}

Trees and shrubs planted for windbreak purposes on the Great Plains have a very important economic and aesthetic impact, therefore using the cost of establishment and benefits derived and compounded through the years is not realistic. A more realistic value needs to be placed on our tree plantings to receive the respect they deserve. A tree with the average life of 100 years destroyed at 50 years of age just cannot be replaced. As age is such an important factor there are two alternatives recommended.

For a belt up to 15 years of age the "Establishment Value" is realistic. This seems practical as most young shelterbelts can be replaced in a reasonably short time to provide comparable protection. The younger shelterbelts should be valued by determining the establishment cost, plus cost of annual crop loss, taxes, and other fixed costs of maintaining the land in trees.

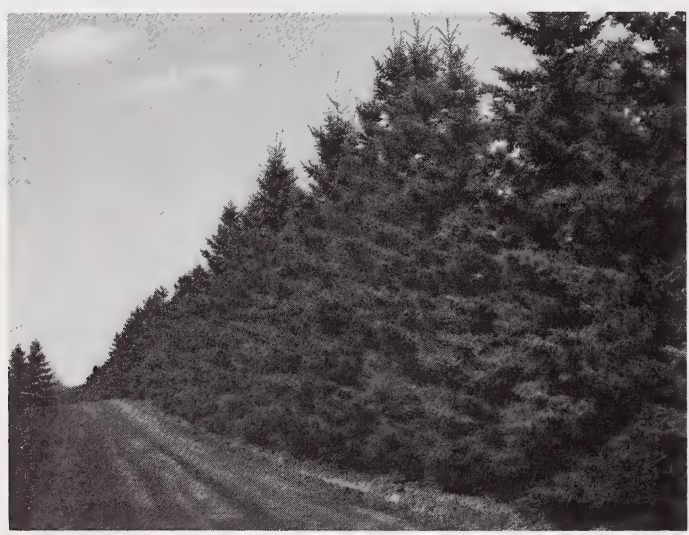

A high value is placed on windbreak trees such as the ones shown.

\section{Establishment Value}

Includes costs of land preparation, planting, cultivation and other maintenance for the first 5 years for all types of plantings
A cost of $\$ 1250+(.22 \times 1250)(1985 \$)$ is estimated for establishing a stand of 1000 trees per hectare. A 4\% (.22) interest adjustment is made for 5 years. It includes preparation costs, planting costs, maintenance for the first 5 years (estimated to be establishment time.) The cost is then $\$ 1.53$ per tree.

\section{Protection Value}

Used when croplands are being protected; a value for the crop is needed. Includes present and future benefits to agricultural crops in terms of net yield increase owing to reduced wind and evaporation. Some assumptions concerning average crop yield and value are necessary to arrive at a monetary value for cropland protection.

To be properly evaluated, the windbreak or shelterbelt must be viewed as a continuous integrated unit. The removal of a single tree or group of trees must be judged as to its effect on the total shelter loss, not on individual tree loss. A scattered group of trees along the fence line of a grain field could be more of a hindrance and removing them may be of benefit to the landowner.

The protected acreage is arrived at by multiplying the length (metres) of the belt by the distance (metres) to which protection extends on one side of the belt. The result is divided by 10,000 (square metres per hectare) to convert to number of hectares protected. The significant protection distance is the average height of tallest trees multiplied by 15 .

\section{Example:}

Dense shelterbelt $0.8 \mathrm{~km}$ long and $12 \mathrm{~m}$ average height would protect 14.4 ha.

$$
\text { i.e. } \frac{800 \mathrm{~m} \times(12 \mathrm{~m} \times 15)}{10,000}=14.4 \mathrm{ha}
$$

Since the average shelterbelt will grow into a different height class each 5 years over a 45 year life span, the calculation of protected area must be increased each 5 years.

\section{Assumptions}

The assumptions made to arrive at the basic field value had to be based on average situations. Alberta farmers follow a multi crop system with various crops being planted over the years. It would be an impossible task to value the crop on a year by year basis. The average prices were based on 1984 grain values and dollars. 
EXAMPLE I - 15 year old belt at $7.5 \mathrm{~m}$

\begin{tabular}{|c|c|c|c|c|}
\hline Age & Height (m) & Years & $\begin{array}{l}\text { Protected Area } \\
\text { for Each } 0.1 \mathrm{~km} / \mathrm{ha}\end{array}$ & Year-Hectares \\
\hline 15 & $7.5-10.5$ & 5 & 1.4 & 7.0 \\
\hline 20 & $10.5-13.5$ & 5 & 1.8 & 9.0 \\
\hline 25 & $13.5-15.0$ & 5 & 2.1 & 10.5 \\
\hline \multirow[t]{2}{*}{$25-45$} & $15+$ & 20 & 2.6 & 52.0 \\
\hline & & 35 & & 78.5 \\
\hline
\end{tabular}

78.5-year hectares $\times \$ 10.00 /$ hectare per year. $\$ 785.00$ for each $0.1 \mathrm{~km}$ segment appraised. (Protection Value)

EXAMPLE II-A 25 year old belt with an average height of $14 \mathrm{~m}$.

\begin{tabular}{|c|c|c|c|c|}
\hline Age & Height (m) & Years & $\begin{array}{l}\text { Protected Area } \\
\text { for Each } 0.1 \mathrm{~km} / \mathrm{ha}\end{array}$ & Year-Hectares \\
\hline 25 & $13.5-15$ & 5 & 2.1 & 10.5 \\
\hline \multirow[t]{2}{*}{$25-45$} & Over 15 & 20 & 2.6 & 52.0 \\
\hline & & $\overline{25}$ & & 62.5 \\
\hline
\end{tabular}

62.5 year-hectares $\times \$ 10.00$ per hectare year $=\$ 625.00$. (Protection Value)

Thus the younger windbreak has a higher protection value than the older windbreak because its protection value is increasing over a longer period of years. A planting already 25 years old can be expected to function for another 20 to 25 years at which time replacement must be made. A 45 year expected life span is average. On good moist land expected life span should be increased to 60 years.

These examples of protection value calculation are for shelterbelts of average or better density, uniformity and continuity. For windbreaks containing many gaps and openings throughout, or for rows of scattered trees the calculated value must be reduced by the number of openings or gaps, e.g., a windbreak with a $50 \%$ gap will be reduced in value by $50 \%$

To arrive at the value of native or natural windbreaks only the protection value is determined and reduced as required. Where native plants (trees/shrubs) are being removed, making homes less 'private', compute the protection value and increase by a factor of three. These will be plantings on the east or south of properties where no obvious wind protection is being afforded by the plants. This is a difficult calculation as no cost/benefit is lost with the loss of privacy.

Protection value for farmstead windbreaks (around the farm house and environs): Value should be five times that computed for a field shelterbelt.
Research has clearly shown that trees and other plants correctly located are energy-conserving, and provide a cooling effect in summer and a warming effect in winter. Trees positioned to function in this manner are worth more than the same plants situated elsewhere.

Windbreaks may be most effective when placed close to buildings, even though maximum wind speed reduction near ground level takes place about five heights downwind from the tree barrier. Basically, plants can be placed near buildings to control or guide wind by obstruction, deflection, and filtration.

\footnotetext{
EXAMPLE III - A 25 year old farmstead belt 13.5 - 15 $\mathrm{m}$ high would be worth $\$ 565.00 \times 5=$ $\$ 2825.00$ for each $0.1 \mathrm{~km}$ segment.
}

The total value then is the sum of the establishment value and the protection value on a $0.1 \mathrm{~km}$ segment (assuming 470 trees per $0.1 \mathrm{~km}$ ). For the 25 year old windbreak the value is $\$ 565.00+(470 \times 1.10)=$ $\$ 1082.00$. A farmstead belt with the same number of trees then can be valued at $565 \times 5=2825+517=$ $\$ 3342.00$.

MOST IMPORTANT: PROFESSIONAL JUDGMENT! 


\section{Net Value Increase of Protected Area}

Basic value of $\$ 10$ year-hectare protected can be applied to grain and similar annual crops. For forage or range crops, the value is reduced to $\$ 8 /$ year-hectare. The basic value $\times .8$ can be used.

Basic value adjustments:

Livestock feedlot areas are calculated at $\$ 40$ yearhectare, or where concentrated quarters such as dairying are protected. Range livestock is based on $\$ 10$ /yearhectare. The basic value $\times 4$ can be used.

Farmstead protection value where buildings and the home are protected is assigned a $\$ 50$ /year-hectare value or $\times 5$ the basic field value.

It has been shown that farm homes and buildings can reduce the heating and cooling cost by $40 \%$ with the proper use of trees for windbreaks and shelter.

Where there are two or more possible values that could be used, the higher value is to be used.

\section{Life Expectancy of Shelterbelt Trees}

In the multirow belt, the longest lived tree is adjudged to be the effective life of the total belt.

\section{TABLE 1}

LIFE EXPECTANCY OF TREES PLANTED IN ALBERTA'S SHELTERBELTS

\begin{tabular}{lcc}
\hline & Ave. Age & Value \\
\hline Hedgeplants & 50 Years & 1.1 \\
Small Deciduous & 65 years & 1.3 \\
Tall Deciduous & & \\
- Poplar, Willow & 30 years & .75 \\
- Maple, Ash & 60 years & 1.2 \\
- Oak & 75 years & 1.4 \\
- Birch & 40 years & .8 \\
Coniferous Trees & 65 years & 1.3
\end{tabular}

\section{Multi Row Factor}

Wind and noise reduction can be equated to the number of rows. The wider the belt, the greater the reduction.

\section{TABLE 2}

\begin{tabular}{ll}
\hline & Value \\
\hline Single Row & 1.0 \\
2 rows & 1.3 \\
3 rows & 1.5 \\
4 rows & 1.65 \\
5 rows & 1.8
\end{tabular}

\section{Tree Condition Overall Value}

- Above average growth, regular cultivation, maintenance, pruning, thinning, tree replacement .... 1.0

- Average growth, structurally sound, occasional cultivation and pruning; some thinning and removal of dead and diseased trees . . . . . . . . . . . .

- Decadent and weakened tree growth, no pruning; dead and diseased branches evident . . . . . . . 8

- No pruning, thinning or removal of dead and diseased branches and trees ................... 65

\section{Design}

To be effective, the windbreak must be properly designed and planted.

\section{TABLE 3}

\begin{tabular}{lr}
\hline & Value \\
\hline Ideal design/planting & $1.0-1.2$ \\
South or East planting & $.8-1.0$ \\
Too close to or too far from buildings & $.2-.5$
\end{tabular}

\section{Time Adjustment}

When destruction occurs and a replacement is planted, the time difference is adjusted. The time difference is the age of the destroyed trees less the age of the replacement.

\begin{tabular}{lc} 
Difference & Value \\
\hline $0-5$ years & 1.0 \\
$6-10$ & 1.2 \\
$11-15$ & 1.4 \\
$16-20$ & 1.6 \\
$21-25$ & 1.8 \\
$26-30$ & 2.0 \\
$31-35$ & 2.1 \\
$36-40$ & 2.2 \\
$41-45$ & 2.5 \\
$46-50$ & 2.0 \\
$51-60$ & 1.6 \\
$60+$ & 1.0
\end{tabular}

\section{Example}

A 3 row 15 metre high farmstead belt, planted in 1955, $1.2 \mathrm{~km}$ long, made up of caragana, maple and scotch pine. There is evidence of disease. The belt was well designed and planted on the north and east side with no major breaks or openings. The owner is a cereal grain farmer. 


\begin{tabular}{ccrcr}
\hline Age & Height & Years & $\begin{array}{c}\text { Protected Area for } \\
\text { Each } 0.1 \mathrm{~m} / \mathbf{h a}^{*}\end{array}$ & Year/Hectares \\
\hline 35 & $15 \mathrm{~m}$ & 5 & $2.7(1)(5 \times 2.7)$ & 13.5 \\
$35-45$ & over $15 \mathrm{~m}$ & 10 & $3.2(2)(10 \times 3.2)$ & 32.0 \\
\hline
\end{tabular}

The basic value then is $45.5 \times \$ 10 /$ hectare/year or $\$ 455.00$ for each $.1 \mathrm{~km}$ segment. In this case, $1.2 \mathrm{~km}$ is being appraised. Therefore, $\$ 455.00 \times 12$ segments equals $\$ 5,460.00$

\begin{tabular}{|c|c|c|c|c|}
\hline Life Expectancy & $\begin{array}{l}\text { Type of Belt } \\
\text { Farmstead }\end{array}$ & $\begin{array}{c}\text { Rows } \\
\text { Multirows (3) }\end{array}$ & Tree Condition & Design \\
\hline 1.3 & 5 & 1.5 & .8 & $1.0 x$ \\
\hline \multicolumn{5}{|c|}{$\$ 5,460.00 \times 1.3 \times 5 \times 1.5 \times .8 \times 1.0=\$ 42,588.00$} \\
\hline
\end{tabular}




\section{SECTION THREE \\ NATURAL TREE AREAS, \\ EXCLUDING NATIVE WINDBREAKS}

There has been consideration given to the evaluation of native tree cover where there is no obvious shelter given or privacy reduced. The formula developed can be used to arrive at the actual value of trees that may have been destroyed or damaged, or are to be condemned because of land use change. All of the accrued costs are included; intrinsic or sentimental values are not considered. All values in 1985 dollars.

\section{The formula considerations:}

1. To include planting costs, (on 1800 trees/ hectare) based on current wage rates and adjusted for the length of time the planting will take. Also to include land preparation.

2. Annual expenses and their amortization for the five year establishment period i.e. $4 \%(.04)$ used in this calculation or $2 \%(.22)$ for five years.

3. To provide for land preplanting rehabilitation. Mainly labor to remove dead or extensively damaged trees, it should include time to burn or dispose of windrows, etc.

$$
\left.V=P+(P \times C)+5 \frac{(E}{R} \times C\right)+L
$$

$\mathrm{V}=$ Value of Natural Planting

$\mathrm{P}=$ Planting Costs, includes labor, trees and other costs as well as preplanting land preparation

C $=$ Interest factor

$5=$ Number of years to establishment
$\mathrm{E}=$ Annual expenses, to include taxes, land investment charges, cultivation and other maintenance charges

$\mathrm{R}=$ Annual interest rate as a decimal, .04 (4\%)

$\mathrm{L}=$ Land rehabilitation charges where needed

Example, using full formula, assume one hectare, five year establishment time for a native site replanted to variety of plants. No fencing (fencing would be added cost at current fencing rates).

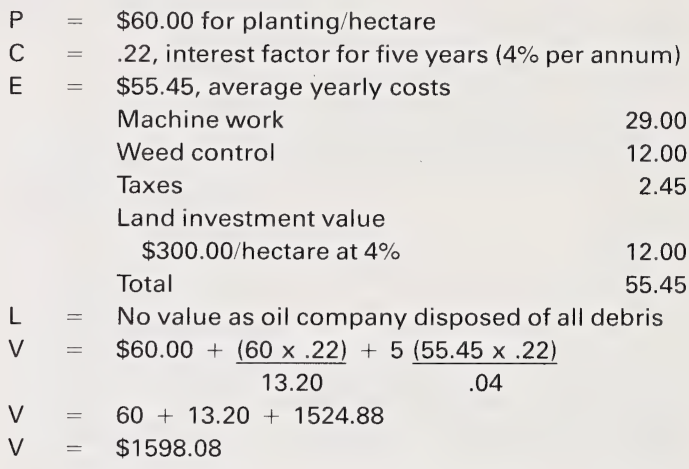

To this value must be added the cost of the trees, which will vary according to the variety and source.

Using the shelterbelt establishment cost of $(1250 \mathrm{x}$ .22) $+1250=\$ 1525.00$, one can arrive at a similar per hectare value. This can be used on smaller areas, the discrepancy increases with larger areas. 


\section{Appendix I \\ TREE RATINGS FOR ALBERTA}

CLASS - SPECIAL - $110 \%$

Acer platanoides, cultivars

Acer saccharinum, cultivars

Acer saccharum

Picea pungens, cultivars

CLASS NO. $1-100 \%$

Abies balsamea

Abies lasiocarpa

Abies sibirica

Acer platanoides

Acer saccharinum

Aesculus glabra

Aesculus hippocastanum

Betula albo-sinensis

Betula verrucosa cultivars

Fraxinus americana

Fraxinus mandschurica

Fraxinus nigra and cultivars

Fraxinus pennsy/vanica lanceolata and cultivars

Larix sibirica

Picea pungens

Pinus albicaulis

Pinus cembra

Pinus flexilis

Pinus strobus

Pinus sylvestris

Pseudotsuga menzies glauca

Quercus alba

Quercus macrocarpa

Quercus rubra/borealis

Syringa reticulata

Thuja occidentalis

UImus americana and cultivars

CLASS NO. $2 A-90 \%$

Populus tremula erecta

Populus canescens "Tower"

Sorbus aucuparia cultivars

Tilia americana cultivars

Tilia cordata cultivars

Tilia flavescens "Dropmore"

UImus japonica cultivars

CLASS NO. $2-80 \%$

Abies concolor

Acer ginnala

Betula papyrifera

Larix decidua

Malus cultivars

Phellodendron amurense

Picea abies
Picea glauca

*Populus species

Prunus maacki

Pyrus ussuriensis

Salix alba sericea

Sorbus americana

Sorbus aucuparia

Sorbus decora

Sorbus scopulina

Tilia americana

Tilia cordata

Tilia mongolica

Ulmus japonica

CLASS NO. 3A $-70 \%$

Populus x "Griffin"

Salix selections

CLASS NO. $3-60 \%$

Acer tataricum

Alnus glutinosa

Alnus tenuifolia

Betula occidentalis

Elaeagnus angustifolia

Juglans cinerea

Juglans nigra

Larix laricina

Malus baccata

Ostrya virginiana

Pinus banksiana

Pinus contorta latifolia

Pinus ponderosa

Pinus resinosa

*Populus species

*Populus hybrids

Prunus nigra

Prunus padus

Prunus pensylvanica

Prunus virginiana "Schubert"

* Salix species

CLASS NO. $4 \mathrm{~A}-50 \%$

Acer negundo

Celtis occidentalis

Crataegus species

Juglans mandshurica

Picea mariana

*Populus hybrids

Ulmus pumila

* Salix species

${ }^{*}$ Range, because of number of species or hybrids 


\section{Appendix II \\ DIAGNOSTIC FACTORS TO \\ CONSIDER IN TREE APPRAISALS}

I. Kind - Scientific Name

Common Name

1. Value depends on:

- Site adaptability:

Hardiness (zone)

Tolerance to drought, storms, wind, ice,

etc.

Soil type, texture, structure, and $\mathrm{pH}$

Drainage

Exposure

Slope and grade extent

Pollution adaptability

Native to area

- Positive characteristics:

Durability

Sturdy branching habit

Important bark, foliage, flower, and fruit characteristics

Required maintenance

- Negative characteristics

Bad habits

Susceptibility to insects and diseases

Undesirable flowers and fruit

2. Age and life expectancy

\section{RATING PERCENTAGE 1 TO $110 \%$}

II. Size

1. Trees:

- general

- caliper of trunk

- area of cross-section

a) diameter squared $\times 0.7854$

2. Multiple stem trees:

- cross-section of largest trunk +40 to $60 \%$ of combined total of other trunks. Specimens required to furnish same degree of shade

\section{RATING PERCENTAGE 1 TO $100 \%$}

III. Condition (See appendix III for chart)

1. General

- Very few are perfect specimens

- Know typical characteristics of species or cultivar and relate to perfect specimen

- What has been previous treatment?

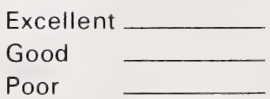

Pruning

Fertilization
Spraying

Cabling and bracing

Tree injection

Herbicide applications or other materials applied

- Have significant changes been made to the environment?

Grade changes; cuts and fills

Changes in water table by flooding or drainage

Pavement: how near, materials, when installed

Utility wires in contact with tree

Utility underground excavation: sewer, gas, electric lines

Injury from guy wires or other supports

Change in habitat: forest to open status

- When and how planted?

Soil cover around tree

Water practices

2. Specifics

- Foliage

Abnormal appearance of leaves

Size

Number

Density

Color

Deficiency symptoms

Wilting

Prevalence of insects and diseases

- Twigs:

Annual twig growth

Abnormal appearance of buds

color, shape, size

Abnormal dropping of twigs

Girdling

Prevalence of insects and diseases

Discoloration of bark and sapwood

- Larger branches:

Amount of dead wood

Excessive pruning

Rate of wound healing

Prevalence of insects and diseases

Borer and bark beetle damage

Rots and fungi

Cankers and lesions

Wire, cable or rod damage

- Trunk of tree

Structural weaknesses and physical defects;

Splits and weak crotches

Loose bark

Sunken area in basal trunk

Frost cracks and condition 


\section{Appendix II (continued) \\ DIAGNOSTIC FACTORS TO \\ CONSIDER IN TREE APPRAISALS}

Cavities

Size, depth, extent, and condition

Previous treatment

Callus healing

Prevalence of old pruning wounds

Extent of healing

Prevalence of insects and diseases

Borers and fungi

Slim flux: origin, extent, and condition

Enlarged basal trunk

Graft incompatibility or other cause

Lightning injury and condition

Electrical burning from wires

Mechanical injuries

Prevalence of suckers or water sprouts

Extent of wood decay

Use increment borer to determine

- Roots:

Evidence of girdling roots at or below surface

Color of feeding rootlets

Extent and color
Mechanical injuries

Exposure due to soil removal and tunneling and trenching

Prevalence of insects and diseases

Cankers and crown rot

Methane gas in old land fill sites

- Condition of other plants in location of a similar kind

\section{RATING PERCENTAGE 1 TO 100\%}

\section{Location}

1. General

- Residential, mall, park, street, arboretum, industrial, woodlot, etc.

- Specifics: Specimen, foundation, screen hedge, windbreak, etc.

2. Design

- Does plant fit the requirements of the specific location?

Size potential, habit, growth rate, etc. Architectural and engineering features:

Space articulation, traffic control, etc

Balance and symmetry 


\section{Appendix III}

TREE DIAGNOSIS AND

CONDITION CHART

\begin{tabular}{|c|c|c|}
\hline Factors to Consider & $\begin{array}{c}\text { Check-off } \\
\text { ratio } \\
(1-10)\end{array}$ & Comments \\
\hline $\begin{array}{l}\text { General } \\
\text { Is tree native to area } \\
\text { Transplanted or natural } \\
\text { Condition of other trees } \\
\text { in area } \\
\text { Foliage } \\
\text { Abnormal appearance of } \\
\text { leaves } \\
\text { Size } \\
\quad \text { Number } \\
\text { Color } \\
\text { Deficiency symptoms } \\
\text { Wilting } \\
\text { Presence of insects and } \\
\text { disease } \\
\text { Twigs } \\
\text { Annual twig growth } \\
\text { Abnormal appearance of } \\
\text { buds } \\
\text { Color } \\
\text { Size } \\
\text { Discoloration of sapwood } \\
\text { or streaking } \\
\text { Prevalence of insects and } \\
\text { disease } \\
\text { Amount of dead wood } \\
\text { Rate of wound healing } \\
\text { Structural weakness }\end{array}$ & & \\
\hline
\end{tabular}

\begin{tabular}{|c|c|c|}
\hline Factors to Consider & $\begin{array}{c}\text { Check-off } \\
\text { ratio } \\
(1-10)\end{array}$ & Comments \\
\hline $\begin{array}{l}\text { Trunk } \\
\text { Splits or weak crotches } \\
\text { Loose bark } \\
\text { Sunken area in basal } \\
\text { trunk } \\
\text { Frost cracks } \\
\text { Cavities } \\
\quad \text { Size } \\
\text { Condition } \\
\quad \text { Callus healing } \\
\text { Prevalence of insects and } \\
\text { disease } \\
\text { Lightning injury } \\
\text { Mechanical } \\
\text { Roots } \\
\text { Girdling roots } \\
\text { Color of feeding rootlets } \\
\text { Exposure of cuts } \\
\text { Gas or herbicide injury } \\
\text { Soil } \\
\text { Type } \\
\text { pH } \\
\text { Drainage } \\
\text { Slope and grade } \\
\text { Previous treatments } \\
\text { Fertilization } \\
\text { Pruning } \\
\text { Spraying } \\
\text { Cabling and bracing }\end{array}$ & & \\
\hline
\end{tabular}




\section{SUGGESTED READING LIST}

1. Woody Ornamentals for the Prairie Provinces, $H$. Knowles, U. of A. Bulletin \#58, 1975.

2. Planting Farm, Field \& Roadside Shelterbelts in Alberta. Alberta Tree Nursery \& Horticulture Centre, Alta. Agriculture.

3. Trees \& Shrubs for the Northern Plains, Donald G Hoag, North Dakota Institute for Regional Studies, North Dakota State University, Fargo, 1965.
4. Manual of Cultivated Trees and Shrubs, Alfred Rehder, 2nd Edition, Macmillan Publishing Co., 1974

5. Native Trees of Canada, R. C. Hosie, Canadian Forest Service, Fisheries and Forestry, Environment Canada, 1969

6. Evolution of Field Windbreaks, R. A. Read, Research Forester, Lincoln, Nebraska, November 1. 1962. 



